\title{
Diet of the Barn Owl (Tyto alba) (Strigiformes: Tytonidae) in the Saharan Touggourt Area (Algeria)
}

Dieta de la lechuza común (Tyto alba) (Strigiformes: Tytonidae) en el área sahariana de Touggourt (Argelia)

Moussa Hadjoudj ${ }^{*}$, Mohammed Lamine Benhaddya1, Karim Souttou², Salaheddine Doumandji ${ }^{3}$

1 Scientific and Technical Research Centre for Arid Areas (C.R.S.T.R.A.), R N 3 Ain Sahara Nezla - BP 360 Touggourt, RP 30200, Ouargla, Algeria.

2 University of Djelfa, Faculty of Natural and Life Sciences, Department of Agronomy, Djelfa, Algeria. kasouttou@yahoo.fr

3 Department of Zoology, National Agronomic Superior School, El Harrach, Algiers, Algeria. dmndjislhdn@yahoo.fr

* Corresponding author / Autor corresponsal: mhadjoudj@gmail.com

\begin{abstract}
The Barn Owl, Tyto alba (Scopoli, 1769), is a nocturnal raptor species. Their diet includes small vertebrates, mainly rodents, and birds. To study their feeding in the desert area of Touggourt, we collected 153 pellets at the Ranou palm grove. We found 468 specimens belonging to 62 species. In terms of abundance, the item more consumed was Rodents (35.9\%) followed by Insects (35.2\%) and Birds (10.7\%). In terms of absolute abundance, the prey more consumed was Brachytrypes megacephalus $(21.4 \%)$, followed by an undetermined Lacertidae species (9.2\%) and Gerbillus nanus (8.8\%). In terms of biomass, rodents contributed more to the diet of Tyto alba (44.66\%) than birds (34.3\%) and reptiles (12.06\%). The highest value of biomass corresponded to Streptopelia sp. (15.7\%), followed by Rattus rattus (14.1\%) and an undetermined Lacertidae species (11.8\%). To our knowledge, this is the first assessment of the diet composition of Tyto alba in the Saharan Touggourt area.
\end{abstract}

Keywords - Birds, Insects, Rodents, diet composition, predator-prey interactions.

Ref. bibliográfica: Hadjoudj, M.; Benhaddya, M. L.; Souttou, K.; Doumandji, S. 2020. "Diet of the Barn Owl (Tyto alba) (Strigiformes: Tytonidae) in the Saharan Touggourt Area (Algeria)". Acta zoológica lilloana 64 (1): 30-42. Fundación Miguel Lillo, Tucumán, Argentina. D.O.I.: https://doi.org/10.30550/j.azl/2020.64.1/3 > Recibido: 26 de enero de 2020 - Aceptado: 12 de mayo de 2020 


\section{RESUMEN}

La lechuza común, Tyto alba (Scopoli, 1769), es una especie de rapaz nocturna. Su dieta incluye pequeños vertebrados, principalmente roedores y aves. Para estudiar su alimentación en el área desértica de Touggourt, recolectamos 153 egagrópilas en el palmeral de Ranou. Encontramos 468 especímenes pertenecientes a 62 especies. En términos de abundancia, el artículo más consumido fue Roedores (35,9\%) seguido de Insectos (35,2\%) y Aves (10,7\%). En términos de abundancia absoluta, la presa más consumida fue Brachytrypes megacephalus (21.4\%), seguida de una especie indeterminada de Lacertidae (9.2\%) y Gerbillus nanus (8.8\%). En términos de biomasa, los roedores contribuyeron más a la dieta de Tyto alba (44,66\%) que las aves (34,3\%) y los reptiles (12,06\%). El valor más alto de biomasa correspondió a Streptopelia sp. (15,7\%), seguido de Rattus rattus (14,1\%) y una especie indeterminada de Lacertidae $(11,8 \%)$. Hasta donde sabemos, esta es la primera evaluación de la composición de la dieta de Tyto alba en el área sahariana de Touggourt.

Palabras clave - Aves, insectos, roedores, composición de dieta, interacciones depredadorpresa.

\section{INTRODUCTION}

In Algeria, there are thirty-three species of diurnal raptors, and seven species of nocturnal raptors; all are protected by law (Decree Number 83-509, 20 August 1983). Among them, the Barn Owl, Tyto alba (Scopoli, 1769), is a nocturnal raptor of the Tytonidae family. This raptor is one of the most widespread birds on the planet (Clark, Smith, Kelso, 1978). But, new molecular studies on Tyto alba have proposed three main clades from Tyto alba complex; Tyto alba (Africa, Europe), Tyto furcata (New World; including bargei) and Tyto javanica (Australasia; including T. j. delicatula and T. j. stertens) (Enríquez, Eisermann, Mikkola, Motta-Junior, 2017). This species complex has a large distribution area in the five continents and occupies mainly open areas, anthropogenic areas, and forests (Venable, 1997; Brito et al., 2015).

Tyto alba hunts silently over roads, barns, buildings, and around farmlands. Many species are the prey of Tyto alba such as rats, mice, shrews, small birds, and arthropods (Sekour et al., 2010; Milchev, 2015). Tyto alba species also occupy agricultural areas where they specialized in predation of small mammals, but the identity of the prey species hunted vary given their accessibility (Taylor, 1994; Tores, Motro, Motro, Yom-Tov, 2005; Miltschev and Georgiev, 2009; Bernard et al., 2010). They contribute to the limitation of the size of prey populations even if the sample taken may appear low (Ramade, 1984).

In the world, many researchers worked on the diet composition of the Tyto alba. These studies have as objective to improve our knowledge on the diet ecology of the raptor and the structure and composition of its prey, particularly micromammals (Sekour et al., 2014). Faúndez, Osorio, Henríquez, Orozco, and Alvarado (2016) in Chile worked on the diet of American Barn owl (Tyto furcata, Temminck, 1827) at 
Acatama desert. In Northern of Lebanon, Abi-Said, Shehab, Amr (2014) published a research on the diversity of small mammals consumed by Tyto alba. Near from Lebanon, Shehab, Daoud, Kock, Amr (2004) recorded a list of small mammals in Syria. Other researchers can be cited such as Nghipangelua and Lukubwe (2017) in Namibia; Leonardi and Dell'Arte (2006) in Tunisia; Rihane (2005) in Doukala (Morocco). In Algeria, authors concentrate their research in the north part of the country such as Boukhemza (1989) in Algiers; Baziz, Doumandji, Hamani (1999) in different areas of northern Algeria; Sekour et al. (2010) in Mergueb; Souttou et al. (2015) in Djelfa; and Ouarab and Doumandji (2017) near of Algiers; but in the southeast part of Algeria (Sahara), this information is rare or absent. For that, this study has the objective to provide a first assessment of the diet composition of Tyto $a l b a$ in a Saharan region (Touggourt) and to establish an inventory of prey species of this area.

\section{MATERIALS AND METHODS}

Study area.- Our study was conducted within Touggourt region, in the southeast of Algeria (33 $02^{\prime}-33^{\circ} 12^{\prime} \mathrm{N}, 5^{\circ} 59^{\prime}-6^{\circ} 14^{\prime} \mathrm{E}$ ) (Fig.1). The study region represents the highest part of the Oued Righ area. In the south and east, Touggourt is limited by the Great Eastern Erg. At the north is bordered by the palm groves of Megarine and in the west by dunes. Touggourt region is located at an altitude of $75 \mathrm{~m}$ (Dubost, 2002; Hadjoudj, Souttou, Doumandji, 2018). The temperature varies between $11.7^{\circ} \mathrm{C}$ in January and $35.1{ }^{\circ} \mathrm{C}$ in July. The average annual rainfall is $155.7 \mathrm{~mm}$. The climate in this region is characterized by a long dry period from February to December and a rainy period in January. The wind speed varies between $10.3 \mathrm{~m} / \mathrm{s}(37 \mathrm{~km} / \mathrm{h})$ in June and $19.5 \mathrm{~m} / \mathrm{s}(70.2 \mathrm{~km} / \mathrm{h})$ in March.

Pellet sampling.- Tyto alba consumes prey whole and later regurgitates the indigestible material, including fur and bones, as a pellet (Taylor, 1994). We collected 153 pellets under the nest of one Tyto alba in an abandoned house located in the Ranou palm plantation $\left(33^{\circ} 03^{\prime} \mathrm{N}, 6^{\circ} 03^{\prime} \mathrm{E}\right)$. The sampling was carried out for 9 months between February 2009 to January 2010. It is by the wet method that the analysis of the pellets was done (Sekour et al. 2014; Souttou et al. 2015; Ouarab and Doumandji, 2017). We dissected Tyto alba pellets individually by hand with a fine plier. After that, we carefully separated bones, fur, and arthropod fragments to identify the species composition of each pellet. The identification of invertebrate prey species was based on dichotomous keys and collections of the Agricultural and Forest Zoology Department (ENSA, Algiers) that were also used as a reference. With regard to vertebrates, we used also identification key if it was necessary: Cuisin (1989) for birds; Osborn and Helmy (1980), Orsini, Cassaing, Duplantier, Cruset (1982), and Barreau, Rocher, Aulagnier (1991) for rodents; Heim De Balsac and Bourlière (1955), and Aulagnier and Thevenot (1986) for insectivores. 


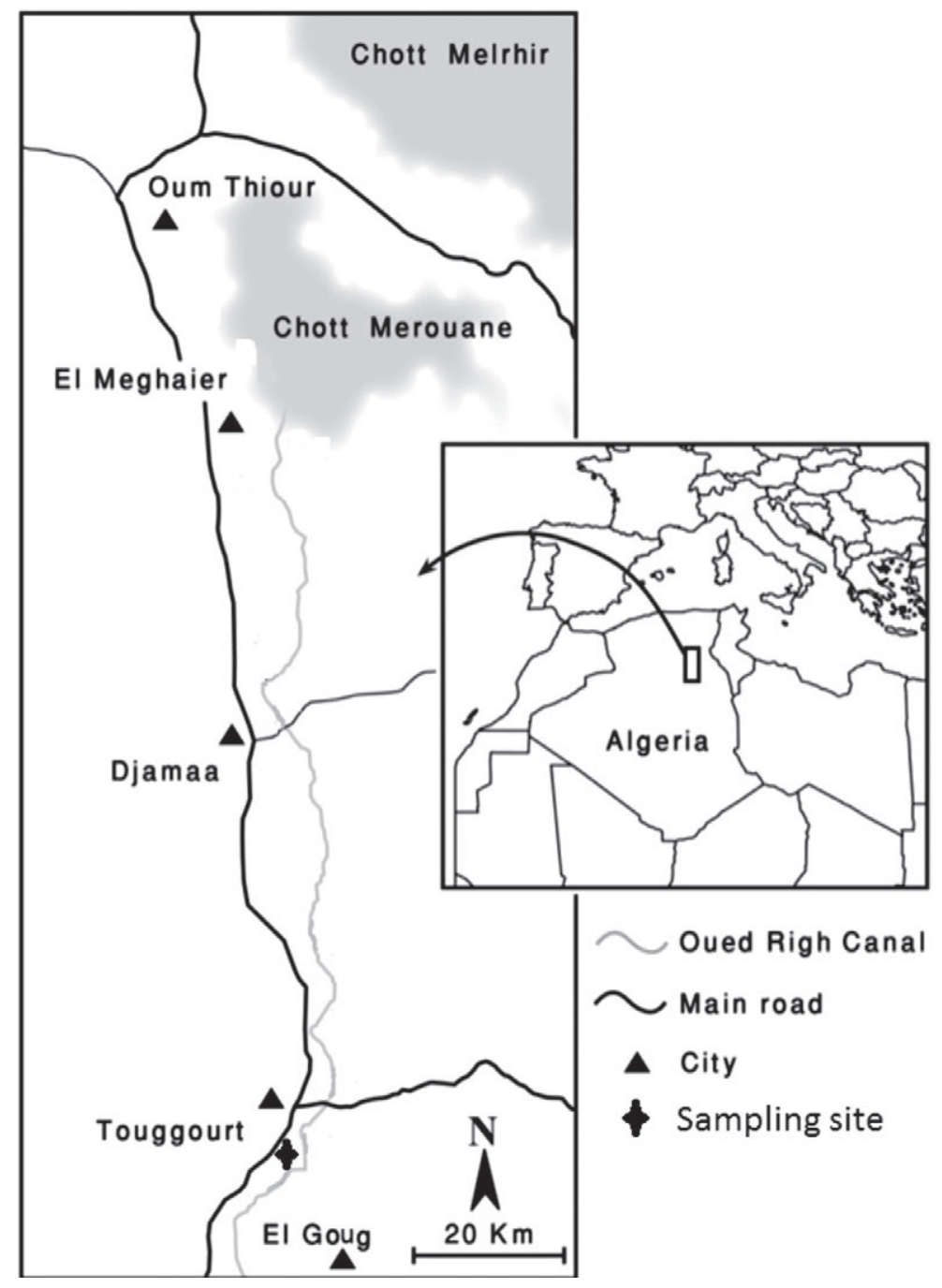

Figure 1. Geographic situation of the sampling area (Touggourt, Southeast Algeria).

Figura 1. Situación geográfica del área de muestreo (Touggourt, Sudeste de Algeria).

Data analysis. - The analysis of our research was based on the total number of species (total richness, S) identified in all Barn Owl pellets (Blondel, 1975; Horn, McMillan, Clair, 2012). The relative abundance (RA\%) is the ratio of the number of individuals from a prey species ( $\mathrm{n}$ ) to the total number of individuals of all prey species (N) (Hamdine, Khammar, Gernigon, 2006; Hadjoudj, Souttou, Doumandji, 2015). A biomass index was estimated using the mean weight of each species. Biomass was calculated by the ratio between the weight of individuals of a determined prey and the total weight of all prey (Vivien, 1973). We also used the ShannonWeaver Index $\left(\mathrm{H}=-\mathrm{Pi}{ }^{\star} \log 2 \mathrm{Pi}\right.$; where $\mathrm{Pi}=\mathrm{ni} / \mathrm{N}$; [ni: number of individuals for each species; N: total number of individuals]) (Sekour et al., 2010; Stoetzel et al., 2016). The evenness index (E) indicated the species distribution in the community ( $\mathrm{E}=\mathrm{H} / \mathrm{Hmax}$; where Hmax $=\log 2 \mathrm{~S}$; [S = total species richness]) (Faurie, Ferra, Médori, Dévaux, Hemptinne, 2006; Hadjoudj et al., 2018). The values vary from 0 (one dominant species) to 1 (all species equally represented in the community). 


\section{RESULTS}

The average length $( \pm$ SD) of the pellets was $43.35 \pm 12.65 \mathrm{~mm}$ and the average diameter was $26.03 \pm 5.82 \mathrm{~mm}$. We identify 468 individual preys. The total richness was 62 prey species; distributed among six categories: Mammals, Aves, Reptilia, Insecta, Malacostraca, and Arachnida. Within Mammals, we recorded the categories Rodentia, Chiroptera, and Soricomorpha (Table 1). The highest relative abundance (RA\%) corresponded to Rodents (35.9\%), and Insects (35.25\%). The abundance of Birds and Reptiles was $10.68 \%$ and $9.61 \%$, respectively. Chiroptera represented $7.48 \%$ of the abundance. The other categories were poorly abundant. In terms of biomass, Rodentia was first with $44.23 \%$ followed by Birds (34.3\%), Reptiles (12.06\%), and Chiroptera (6.38\%) (Table 1).

Among the prey species, Brachytrypes megacephalus was dominant with a relative abundance of $21.4 \%$; followed by an undetermined Lacertidae species $(9.2 \%)$, and Gerbillus nanus (8.8\%) (Table 1). Mus spretus was fourth with $7.7 \%$ of relative abundance; followed by an undetermined species of Chiroptera (7.3\%), and Gerbillus gerbillus (6.6\%). Other species have lower values of relative abundance, ranging between $0.2 \%$ and $3.9 \%$. The biomass values of prey species showed that Streptopelia sp. had the highest percentage (15.71\%); followed by Rattus rattus (14.14\%) (Table 1). An undetermined Lacertidae species occupied the third position with value biomass of 11.8\%; followed by Columba livia (10.2\%). Gerbillus gerbillus, Gerbillus nanus, Mus spretus and Mus musculus had values varying between $2.5 \%$ and $7.1 \%$. The ShannonWeaver index of diversity H' was 4.5 bits; the Hmax was 6 bits; and the Evenness index was 0.8 , meaning a tendency towards a balance among the prey species of Tyto alba.

\section{DISCUSSION}

The size of pellets correlates with the size of the predators because pellet size is proportional to spout width, esophagus diameter, and gizzard size, which directly affect the ability of Tyto alba to capture larger prey (Guérin, 1928; Alivizatos, Goutner, Zogaris, 2005; Sekour et al., 2010). Many studies in Algeria are focused on the Tyto alba diet. To identify and confirm the species studied, we compared the size of our pellets with other Algerian studies and we found them similar. We found similar results to Baziz (2002) from different Algerian sites, and Manaa, Souttou, Sekour, Guezoul, Doumandji (2015) in Ouargla near to Touggourt; from where they have reported pellet sizes $41.1 \pm 11.9 \mathrm{~mm}, 26.0 \pm 6.4 \mathrm{~mm}, 40.21 \pm 5.34$, and $26.1 \pm 3.29$ $\mathrm{mm}$; respectively.

In our study, invertebrates were more represented $(S=34)$ than vertebrates $(S=$ 27). Rocha, Ferreira, Leite, Fonseca, Costa (2011) reported 16 vertebrate items in the diet of Tyto furcata from Central Brazil. In South Bulgaria, Milchev (2015) reported 7 invertebrate and 33 vertebrate species. Stoetzel et al. (2016) analyzed 57 pellets of Tyto furcata in Dominica and mentioned a higher total richness of vertebrates ( $\mathrm{S}$ =37) than invertebrates $(S=7)$. According to Nghipangela and Lukubwe (2017), 
Table 1. Prey items consumed by Tyto alba in the Touggourt area. N, number of individuals; RA $\%$, relative abundance; $\mathrm{B} \%$, biomass; RAc $\%$, relative abundance of categories; $\mathrm{BC} \%$, biomass of categories.

Tabla 1. Presas consumidas por Tyto alba en el área de Touggourt. N, número de individuos; RA\%, abundancia relativa; $\mathrm{B} \%$, biomasa; \% RAc, abundancia relativa de categorías; $\mathrm{Bc} \%$, biomasa de categorías.

\begin{tabular}{|c|c|c|c|c|c|c|}
\hline Class & Species & $\mathbf{N}$ & RA \% & B \% & RAC $\%$ & Bс $\%$ \\
\hline \multirow[t]{2}{*}{ Arachnida } & Solifugea und. sp. & 1 & 0.21 & 0.03 & 0.64 & \\
\hline & Galeodes sp. & 2 & 0.43 & 0.05 & & 0.03 \\
\hline Malacostraca & Oniscus sp. & 1 & 0.21 & 0 & 0.21 & 0.00 \\
\hline \multirow{31}{*}{ Insecta } & Mantis religiosa & 1 & 0.21 & 0 & & \\
\hline & Hodotermes sp. & 1 & 0.21 & 0 & & \\
\hline & Platycleis griseus & 1 & 0.21 & 0 & & \\
\hline & Tropidopola cylindrica & 1 & 0.21 & 0.01 & & \\
\hline & Acrididae und. sp. & 1 & 0.21 & 0.02 & & \\
\hline & Gryllus sp. & 3 & 0.64 & 0.01 & & \\
\hline & Brachytrypes megacephalus & 100 & 21.37 & 2.36 & & \\
\hline & Gryllotalpa gryllotalpa & 2 & 0.43 & 0.05 & & \\
\hline & Labidura riparia & 1 & 0.21 & 0 & & \\
\hline & Scutelleridae und. sp. & 1 & 0.21 & 0 & & \\
\hline & Coleoptera sp. & 2 & 0.43 & 0.01 & & \\
\hline & Cicindela flexuosa & 2 & 0.43 & 0 & 35.25 & 2.51 \\
\hline & Hydrophilus sp. & 1 & 0.21 & 0 & & \\
\hline & Ateuchus sacer & 1 & 0.21 & 0.02 & & \\
\hline & Pentodon sp. & 1 & 0.21 & 0.01 & & \\
\hline & Tenebrionidae und. sp. & 5 & 1.07 & 0.01 & & \\
\hline & Pachychila sp. & 1 & 0.21 & 0 & & \\
\hline & Mesostena angustata & 2 & 0.43 & 0.01 & & \\
\hline & Larinus sp. & 2 & 0.43 & 0 & & \\
\hline & Cyphocleonus sp. & 1 & 0.21 & 0 & & \\
\hline & Rhytirrhinae und. sp. & 2 & 0.43 & 0 & & \\
\hline & Hypera sp. & 1 & 0.21 & 0 & & \\
\hline & Prionus pectinicornis & 2 & 0.43 & 0 & & \\
\hline & Scoliidae und. sp. & 1 & 0.21 & 0 & & \\
\hline & Formicidae und. sp. & 1 & 0.21 & 0 & & \\
\hline & Messor capitatus & 4 & 0.85 & 0 & & \\
\hline & Camponotus sp. & 17 & 3.63 & 0 & & \\
\hline & Cataglyphis sp. & 1 & 0.21 & 0 & & \\
\hline & Pheidole sp. & 3 & 0.64 & 0 & & \\
\hline & Pheidole pallidula & 1 & 0.21 & 0 & & \\
\hline & Tetramorium biskrense & 2 & 0.43 & 0 & & \\
\hline \multirow[t]{2}{*}{ Reptilia } & Lacertidae und. sp. & 43 & 9.19 & 11.82 & & \\
\hline & Agamidae und. sp. & 2 & 0.43 & 0.24 & 9.61 & 12.06 \\
\hline \multirow[t]{10}{*}{ Aves } & Aves und. sp. & 2 & 0.43 & 1.57 & & \\
\hline & Columbidae und. sp. & 1 & 0.21 & 1.02 & & \\
\hline & Columba livia & 10 & 2.14 & 10.21 & 10.68 & 34.3 \\
\hline & Streptopelia sp. & 16 & 3.42 & 15.71 & & \\
\hline & Hirundinidae und. sp. & 1 & 0.21 & 0.15 & & \\
\hline & Sylviidae und. sp. & 7 & 1.5 & 0.99 & & \\
\hline & Lanius excubitor & 6 & 1.28 & 3.3 & & \\
\hline & Passer sp. & 5 & 1.07 & 0.16 & & \\
\hline & Passeriforme und. sp. 1 & 1 & 0.21 & 0.16 & & \\
\hline & Passeriforme und. sp. 2 & 1 & 0.21 & 1.03 & & \\
\hline \multirow[t]{2}{*}{ Chiroptera } & Chiroptera und. sp. & 34 & 7.26 & 6.14 & & \\
\hline & Rhinolophidae und. sp. & 1 & 0.21 & 0.24 & 7.48 & 6.38 \\
\hline \multirow[t]{12}{*}{ Rodentia } & Gerbillus sp. & 3 & 0.64 & 0.6 & & \\
\hline & Gerbillus campestris & 5 & 1.07 & 0.9 & & \\
\hline & Gerbillus gerbillus & 31 & 6.62 & 7.13 & & \\
\hline & Gerbillus nanus & 41 & 8.76 & 5.41 & & \\
\hline & Gerbillus tarabuli & 3 & 0.64 & 0.8 & & \\
\hline & Mus musculus & 17 & 3.63 & 2.54 & & \\
\hline & Mus spretus & 36 & 7.69 & 5.37 & & \\
\hline & Rattus sp. & 5 & 1.07 & 3.93 & & \\
\hline & Rattus rattus & 18 & 3.85 & 14.14 & & \\
\hline & Eliomys quercinus & 2 & 0.43 & 0.82 & & \\
\hline & Jaculus sp. & 1 & 0.21 & 0.43 & & \\
\hline & Jaculus jaculus & 6 & 1.28 & 2.59 & 35.9 & 44.66 \\
\hline Soricomorpha & Suncus etruscus & 1 & 0.21 & 0.02 & 0.21 & 0.00 \\
\hline
\end{tabular}


Tyto alba pellets in Namibia had 18 of vertebrates species and 8 invertebrates ones. In two Algerian steppe regions (M'Sila and Djelfa), Sekour et al. (2014) avowed the equality between invertebrates and vertebrates, with 38 species for each group. We founded a result different from that reported by Ouarab and Doumandji (2017) for the Reghaïa wetland (Algiers), where vertebrates $(S=13)$ were the only prey species of the diet of Tyto alba.

The prey species diversity was greater in our study than other studies cited in our discussion. This richness suggests a potential of Tyto alba hunting in palm groves, dunes, and at the level of the houses closest to its nest in our study area. Tyto alba hunting range estimates are very diverse and range from 0.45 to $6 \mathrm{~km}$ (Smith, Wilson, Frost, 1974; Glutz von Blotzheim, 1980; Taberlet, 1983). Of the twelve species of Rodentia, the Gerbillus genus prefers the sandy soils with the presence of Saharan plantation (Zygophyllum album and Traganum nudatum) (Hamdine et al., 2006; Hadjoudj et al., 2015). In previous work, Mus and Rattus genera were described in 5 palm groves of the Touggourt region (Bebba, Hadjoudj, Baziz, Sekour, Souttou, 2008; Bebba and Baziz, 2009; Hadjoudj et al., 2015).

Bird species were present in the pellets of Tyto alba with Streptopelia sp., Columba livia, Lanius excubitor, and Passer sp. Reptiles (Lacertidae and Agamidae) and Chiroptera were also presented in the list of species consumed in the current research. Hamani (2006) noted that in the absence or rarity of large prey such as Meriones shawi, Psammomys obesus, and Faculus orientalis; Tyto alba attacks smaller prey suggesting varying ecological roles. Brachytrupes megacephalus also was a replacement prey in the palm grove. Chopard (1943) reported the abundance of this desert cricket in southern Algeria and Tunisia. Lakhdari et al. (2015a) and Lakhdari et al. (2015b), mentioned the presence of this cricket in the oasis of Sidi Mehdi (Touggourt) associated to crops and suggest that it causes crop damages. For the rest of insect species present in the pellets, we assume that they could have been consumed by Tyto alba's prey (i.e., rodents, bats, birds, reptiles) because they had very small sizes.

Generally, in arid regions, Tyto alba consumes different categories, such as Gastropoda, Arachnida, Insecta, Batrachia, Reptilia, Aves, Rodentia, Soricomorpha, and Chiroptera (Sekour et al., 2014). In Chile, the diet of Tyto furcata was composed principally of rodents, although also by other categories such as marsupials, birds, and arthropods (Faúndez et al., 2016). Our results were different from those founded by Alia, Sekour, Ould El Hadj (2012) in Oued Souf (Southeast Algeria) where rodents dominated the diet with $88.2 \%$ of abundance. Our observations are also different from those of Sekour et al. (2010) in Ain El Hadjel (Steppe region, Algeria) when they indicated that rodents are the most frequent prey (66.7\%) followed by the insects $(1.02 \%)$ and birds $(0.85 \%)$. On contrary, farther in the south of Touggourt in Ouargla, Manaa et al. (2015) reported variations in the diet of the Barn Owl by ingesting more birds in Mekhadma (64.6\%) and Tazgraret (64.5\%) compared to the rodents. Therefore, the current work disagrees with that of Manaa et al. (2015) realized in Ouargla. Here we found similar values to a study carried out in Morocco, where the diet of Tyto alba was composed of 50.8\% of rodents, $29.4 \%$ of birds, and $15.7 \%$ of insects Rihane (2005). 
The biomass index showed that rodents were the most important part of biomass (44.66\%) followed by birds (34.3\%). This finding agrees with many previous studies. Stoetzel et al. (2016) mentioned that prey biomass was $76.2 \%$ for rodents and $12.2 \%$ for birds from pellets of Tyto furcata in Dominica. In the Atacama desert in Chile, Faúndez et al. (2016) estimated that rodents contributed more significantly (95.3\%) than birds (3.5\%) to the diet of Tyto furcata. Our results are similar to the study of Farhi et al. (2016) in Ziban (Biskra, Algeria) when they found higher biomass for rodents (52.95\%) than birds (43.43\%). The high biomass value registered in our study also is similar to the results of Souttou et al. (2015) in a steppe environment in Algeria, where the biomass of rodents in the diet of Tyto alba was $80.09 \%$.

On the other hand, our results about the abundance of prey species differed from those of Boukhemza (1989) at the National Agronomic Institute of El Harrach (Algeria), who noted that the abundance of insects in the pellets of Tyto alba was modest (1.7\%). Also in Oued Souf (Southeast Algeria), Alia et al. (2012) reported a low presence of insects (3.3\%) while Gerbillus gerbillus (44\%) dominated followed by Gerbillus campestris (13.3\%). Similarly, in Tunisia, Leonardi and Dell 'Arte (2006) noted that Faculus jaculus constitutes the main prey with $50.2 \%$ in the diet of Tyto alba. According to a large group of authors such as Bontzorlos, Peris, Vlachos, Bakaloudis (2005) in Greece; Charter, Izhaki, Meyrom, Motro, Leshemy (2009) in Jordan and Palestine; and Milchev (2015) in Bulgaria; the presence of insects in the pellets of Tyto alba is very low. This variation may be attributed to the type of environment. Manaa et al. (2015) worked in two sites in Ouargla (Southeast Algeria) and they recorded the dominance of Streptopelia sp. in Mekhadma (32.9\%) and Tazgraret (30.3\%), and Passer sp. in Mekhadma (21.9\%) and Tazgraret (27.6\%). For his part, Hadj Benamane (2015) in Ouargla, noted that Streptopelia sp. was the most consumed prey followed by Passer sp. The results of the current work disagree with those of Manaa et al. (2015) and Hadj Benamane (2015) in Ouargla.

In terms of biomass, Streptopelia sp. (15.7\%) occupied the first rank followed by Rattus rattus (14.1\%). The results of the current study confirm that reported by Manaa et al. (2015) in Ouargla. These authors report that the highest biomass was provided by Streptopelia sp. with $43 \%$ at Mekhadma and $62.8 \%$ at Tazgraret. The same authors emphasize that Columba livia came in second place with $15.7 \%$ in Tazgraret and with 35\% in Mekhadma. On the contrary, our observations disagree with those noted in Mâalba (Steppe, Algeria) by Souttou et al. (2015) and of Sekour et al. (2010) in Ain El Hadjel (Steppe, Algeria). Souttou et al. (2015) noted that Meriones shawii and Meriones lybicus represented $40.3 \%$ and $18.8 \%$ of the prey biomass, respectively. Sekour et al. (2010) mentioned that Meriones shawii and Gerbillus sp. represented $85.8 \%$ and $9.5 \%$ of the prey biomass, respectively. According to these latter authors, the biomass of birds was negligible. In Tunisia, Leonardi and Dell 'Arte (2006) registered the highest value of biomass for Faculus jaculus (50.2\%) followed by Meriones lybicus (19.5\%). Also, these latest authors mentioned that birds are poorly represented as Galerida cristata (0.7\%) and Oenanthe sp. (0.7\%). The current research results are different from those of Charter et al. (2009) in Jordan and Palestine when they report that prey biomass was composed exclusively by Meriones sp. 
Based on the results of the Shannon-Weaver and Evenness indexes, we noted that our values are different from those noted by Manaa et al. (2015) in the steppe and Saharan regions. These authors estimated a diversity $\mathrm{H}^{\prime}=2.7$ bits $\left(\mathrm{H}^{\prime} \max =\right.$ 3.46 bits) at Ain El Ibel site and an $\mathrm{H}^{\prime}=2.43$ bits (H'max $=3.32$ bits) in El Mesrane site. The same authors reported an $\mathrm{H}^{\prime}=2.87$ bits (H'max $=4.32$ bits) at Mekhadma and an $\mathrm{H}^{\prime}=2.49$ bits ( $\mathrm{H}$ ' $\max =3.58$ bits) at Tazgraret. Stoetzel et al. (2016) registered low values compared to our observations. These authors mention an $\mathrm{H}^{\prime}=2.21$ bits (H'max $=4.74$ bits) and a weak equitability (0.47). At the Atacama Desert in Chile, Faúndez et al. (2016) report that Tyto furcata consumed a low diversity of prey $\left(\mathrm{H}^{\prime}=0.89\right.$ bits), which differs from the result obtained at Touggourt. In contrast, our values were very close to those of Farhi et al. (2016) in Algeria $\left(\mathrm{H}^{\prime}=4.24\right.$ bits, $\mathrm{H}^{\prime} \max =5.39$ bits and $\mathrm{E}=0.78$ ).

\section{CONCLUSION}

In the present study, the analysis of 153 pellets reveals a high richness of prey species. We found more invertebrate than vertebrate prey species. Among the six categories of prey, rodents and insects were dominant. The prey species found in the diet suggest that Tyto alba hunts in palm groves, dunes, and near to the houses. The prey more frequent was Brachytrypes megacephalus (“djendeb”). Previous studies report a low presence of insects in the Barn Owl diet. Our study suggests that insectivory in Barn Owl is high in Touggourt. Also, the Barn Owl diet presents high diversity. So, it is important to protect Tyto alba, because this raptor contributes to the reduction of harmful species for crops (Souttou et al., 2015; Ouarab and Doumandji, 2017).

\section{ACKNOWLEDGEMENTS}

We are very thankful to the corresponding author's father, Hadjoudj Mohammed Mahmoud for his help during the sampling process.

\section{FUNDING}

No funding sources.

\section{PARTICIPATION}

All authors participated in the study.

\section{CONFLICTS OF INTEREST}

No conflicts of interest. 


\section{LITERATURE CITED}

Abi-Said, M.R., Shehab, A.H., and Amr, Z.S. (2014) Diet of the Barn Owl (Tyto $a l b a$ ) from Chaddra-Akkar, Northern Lebanon. Jordan Journal of Biological Sciences, 7, 109-112.

Alia, Z., Sekour, M., Ould El Hadj M.D. (2012). Importance des rongeurs dans le menu trophique de Tyto alba (Scopoli, 1769) dans la région de Souf (Algérie). Revue Bioressources, 2, 37-47.

Alivizatos, H., Goutner, V., Zogaris, S. (2005). Contribution to the study of the diet of four owl species (Aves, Strigiformes) from mainland and island areas of Greece. Belgian Journal of Zoology, 135, 109-118.

Aulagnier, S., Thevenot, M. (1986). Catalogue des mammiferes sauvages du Maroc. Rabat: Trav. Inst. Sci. Sér. Zool.

Barreau, D., Rocher, A., Aulagnier, S. (1991). Eléments d'identification des crânes des rongeurs du Maroc. Eléments d'identification des crânes des rongeurs du Maroc. Puceul: SFEPM [Société française pour l'étude et la protection des mammifères].

Baziz, B. (2002). Bioécologie et régime alimentaire de quelques rapaces dans différentes localités en Algérie. Cas du Faucon crécerelle Falco tinnunculus Linné, 1758, de la Chouette effraie Tyto alba (Scopoli, 1769), de la Chouette hulotte Strix aluco (Linné, 1758), de la Chouette chevêche, Athene noctua (Scopoli, 1769), du Hibou moyen-duc Asio otus (Linné, 1758) et du Hibou grand-duc ascalaphe Bubo ascalaphus Savigny, 1809. [Thèse Doctorat d'Etat Sci. Agro., Inst. Nati. Agro., El-Harrach, 499 p].

Baziz, B., Doumandji, S., Hamani, A. (1999). Adaptations trophiques de la Chouette effraie Tyto alba (Aves, Tytonidae) dans divers milieux en Algérie. In: Proceedings of International Union of Game Biologists, 24th Congress (217-227), Thessaloniki [20-24 september 1999].

Bebba, K., Baziz, B. (2009). Les micromammifères dans la vallée d'Oued Righ. In: Sémimaire Internati. Biodiversité faunist. zones arides semi-arides (16), Ouargla: Fac. Sci. Vie. Terre, Univ. Kasdi Merbah [22-24 novembre 2009].

Bebba, K., Hadjoudj, M., Baziz, B., Sekour, M., Souttou, K. (2008). Les Murinae d’Oued Righ. In: 3ème Journées Prot. Vég. (67), El Harrach: Dép. Zool. Agri. For., Inst. Nati. Agro. [6-7 avril 2008].

Bernard, N., Michelat, D., Raoul, F., Qur, J.P., Delattre, P., Giraudoux, P. (2010). Dietary response of Barn Owls (Tyto alba) to large variations of common voles (Microtus arvicola) and European water voles (Arvicola terrestris). Canadian Journal of Zoology, 88, 416-426.

Blondel, J. (1975). Lanalyse des peuplements d'oiseaux - éléments d'un diagnostic écologique. La méthode des échantillonnages fréquentiels progressifs (E.F.P). LaTerre et la Vie, 29, 533-589.

Bontzorlos, V.A., Peris, S.J., Vlachos, C.G., Bakaloudis, D.E. (2005). The diet of Barn Owl in the agricultural landscapes of central Greece. Folia Zoologica, 54, 99-110. 
Boukhemza, M. (1989). Données sur le régime alimentaire de la Chouette effraie (Tyto alba) dans la banlieue sub-urbaine d'Alger. Aves, 26, 234-236.

Brito, J.M., Orellana-Vasquez, H., Cadena-Ortiz, H., Vargas, R., Pozo-Zamora, G.M., Curay, J. (2015). Mamíferos pequeños en la dieta de la lechuza Tyto alba (Strigiformes: Tytonidae) en dos localidades del occidente de Ecuador, con ampliación distribucional de Ichthyomys hydrobates (Rodentia: Cricetidae). Papéis Avulsos de Zoologia, 55, 261-268.

Charter, M., Izhaki, I., Meyrom, K., Motro, Y., Leshemy, Y. (2009). Diets of Barn Owls Differ in the same agricultural region. The Wilson Journal of Ornithology, 121, 378-383.

Chopard, L. (1943). Orthoptéroïdes de l'Afrique du Nord. Faune de l'empire français. Paris, France: Larose.

Clark, R.J., Smith, D.G., Kelso, L.H. (1978). Working bibliography of owls of the world: with summaries of current taxonomy and distributional status (N 1). [Raptor Information Center, National Wildlife Federation].

Cuisin, J. (1989). L'identiûcation des crânes des passereaux (Passeriformes-Aves). [Dipl. Sup. Étud. Rech., Université Bourgogne, Dijon].

Dubost, D. (2002). Ecologie, aménagement et développement agricole des oasis algériennes. Biskra: Centre Rech. Sci. Techn. Rég. Arides.

Enríquez, P.L., Eisermann, K., Mikkola, H., Motta-Junior, J.C. (2017). A Review of the Systematics of Neotropical Owls (Strigiformes). In Neotropical Owls (7-19). Cham.: Springer.

Farhi, Y., Hani, K., Ahmat, M.L., Bambra, K.E., Radjah, T., Absi, K., Souttou, K., Belhamra, M. (2016). Première données sur le comportement trophique de la chouette effraie (Tyto alba, Scopoli, 1769) dans la région de Biskra (Sahara septentrionale algérien). Journal Algérien des Régions Arides, 13, 113-120.

Faúndez, P.V., Osorio, N.U., Henríquez, N.Á., Orozco, O.O., Alvarado, S. (2016). Dieta de la lechuza blanca (Tyto alba Scópoli 1769) en el valle de Copiapó, desierto de Atacama, Chile. Interciencia: Revista de ciencia y tecnología de América, 41, 114-118.

Faurie, C., Ferra, C., Médori, P., Dévaux, J., Hemptinne. J.L. (2006). Ecologie: Approche Scientifique et Pratique. Paris: Lavoisier.

Glutz Von Blotzheim, U.N. (1980). Handbuch der Vögel Mitteleuropas. Bd 9, Columbiformes-Piciformes. Akademische Verlagsgesellschaft.

Guérin, G. (1928). L'Effraie commune en Vendée. Encyclopédie ornithologique, t. IV. Paris: Paul Lechevalier.

Hadj Benamane, A. (2015). Variation du régime alimentaire de la chouette effraie dans les palmeraies d'Ouargla. In: 2ème Sémimaire Internati. Biodiv. faunist. zones arides semi-arides (14), Ouargla: Fac. Sci. Vie. Terre, Univ. Kasdi Merbah [29-30 novembre 2015].

Hadjoudj, M., Souttou, K., Doumandji, S. (2015). Diversity and richness of rodent communities in various landscapes of Touggourt Area (Southeast Algeria). Acta Zoologica Bulgarica, 67, 415-420.

Hadjoudj, M., Souttou, K., Doumandji, S. (2018). The diversity of arthropods community in dunes and a palm grove (Phoenix dactylifera) in the Touggourt region 
(Septentrionale Sahara). International Journal of Tropical Insect Science, 38, 283-293.

Hamani, A. (2006). Variation du régime alimentaire de la Chouette effraie Tyto alba (Scopoli, 1759) (Aves, Tytonidae) aux abords du barrage de Boughzoul. [Thèse Magister, Inst. Nati. Agro., El Harrach].

Hamdine, W., Khammar, F., Gernigon, T. (2006). Distribution des Gerbillidés dans les milieux arides d'El Goléa et de Béni-Abbès (Algérie). Soc. Hist. Natu. Afrique du Nord, 73, 45-55.

Heim De Balsac, H., Bourlière, F. (1955). Ordre des Insectivores-Systématique (16531697) [cité par Grassé, P.P.: Traité de Zoologie, Mammifères. T. XVII, fasc. 2 (1172-2300). Paris: Masson et Cie].

Horn, K.J., McMillan, B.R., Clair, S.S. (2012). Expansive fire in Mojave Desert shrubland reduces abundance and species diversity of small mammals. Journal of Arid Environments, 77, 54-58.

Lakhdari, W., Doumandji-Mitiche, B., Acheuk, F., Dehliz, A., M'lik, R., Soud, A., Hammi, H. (2015a). Morphological study of different developmental stages of Brachytrupes megacephalus Lefebvre, 1827 (Orthoptera, Gryllidae) and their development in Oued Righ region (Algerian Sahara). Academic Journal of Entomology, 8, 117-126.

Lakhdari, W., Doumandji-Mitiche, B., Dehliz, A., Doumandji, S., Bouchikh, Y., M'lik, R., Soud, A., Hammi, H. (2015b). Essai de lutte biologique contre Brachytrupes megacephalus, Lefebvre, 1827 (Orthoptera, Gryllinae) par l'utilisation des champignons entomopathogenes. Revue des Bioressources, 5, 37- 49.

Leonardi, G., Dell'Arte, G. L. (2006). Food habits of the Barn Owl (Tyto alba) in a steppe area of Tunisia. Journal of Arid Environments, 65, 677-681.

Manaa, A., Souttou, K., Sekour, M., Guezoul, O., Doumandji, S. (2015). Comportement trophique de la chouette effraie Tyto alba dans des stations à climats semi arides. In: 2ème Sémimaire Internati. Biodiv. faunist. zones arides semiarides (11), Ouargla: Fac. Sci. Vie. Terre, Univ. Kasdi Merbah [29-30 novembre 2015].

Milchev, B. (2015). Diet of Barn Owl Tyto alba in Central South Bulgaria as influenced by landscape structure. Turkish Journal of Zoology, 39: 933 - 940.

Miltschev, B., Georgiev, V. (2009). Der Einfluss von Wühlmaus Gradationen und Rodentiziden auf die brutzeitliche Nahrungszusammensetzung der Schleiereule Tyto alba (Scopoli 1769) in Südost-Bulgarien. Egretta, 50, 82-87.

Nghipangela, P.N., Lukubwe, M.S. (2017). Diet of Barn Owls (Tyto alba) in Katima Mulilo, Zambezi Region, Namibia. International Science and Technology Journal of Namibi, 10, 82-93.

Orsini, P., Cassaing, J., Duplantier, J.M., Cruset, H. (1982). Premières données sur l'écologie des populations naturelles de souris Mus spretus et Mus musculus domesticus dans le Midi de la France. La Terre et la Vie, 36, 321-336.

Osborn, D.J., Helmy, I. (1986). The contemporary land mammals of Egypt (including Sanai). In: Fieldiana Zoology, 5. Field Museum Natural History. 
Ouarab, S., Doumandji, S. (2017). Ecologie trophique de la chouette effraie Tyto alba (SCOPOLI, 1769) dans la réserve naturelle de la zone humide de Réghaïa. Details - Bulletin de la Société Zoologique de France, 142, 13-28.

Ramade, F. (1984). Eléments d'écologie - Ecologie fondamentale. Paris: Mc. GrawHill.

Rihane, A. (2005). Contribution à l'étude du régime alimentaire de la Chouette effraie Tyto alba dans les plaines semi-arides du Maroc (Compléments). Go - South Bull, 2, 37-43.

Rocha, R.G., Ferreira, E., Leite, Y.L.R, Fonseca, C., Costa, L.P. (2011). Small mammals in the diet of Barn owls Tyto alba (Aves: Strigiformes) along the mid-Araguaia River in central Brazil. Zoologia, 28, 709-716.

Sekour, M., Baziz, B., Denys, C., Doumandji, S., Souttou, K., Guezoul, O. (2010). Régime alimentaire de la Chevêche d'athena Athene noctua, de l'Effraie des clochers Tyto alba, du Hibou moyen-duc Asio otus et du Grand-duc ascalaphe Bubo ascalaphus, Réserve naturelle de Mergueb (Algérie). Alauda, 78, 103-117.

Sekour, M., Souttou, K., Guerzou, A., Benbouzid, N., Guezoul, O., Ababsa, L., Denys, C., Doumandji, S. (2014). Importance de la Mérione de Shaw Meriones shawii au sein des composantes trophiques de la Chouette effraie Tyto alba en milieux steppiques de l'Algérie. Comptes Rendus Biologie, 337, 405-415.

Shehab, A.H, Daoud, A., Kock, D., Amr, Z. (2004). Small mammals recovered from Owl pellets from Syria (Mammalia: Soricidae, Chiroptera, Rodentia). Zoology in the Middle East, 33, 27-42.

Smith, D.G., Wilson, C.R., Frost, H.H. (1974). History and ecology of a colony of Barn Owl in Utah. Condor, 70, 131-130.

Souttou, K., Manaa, A., Sekour, M., Ababsa, L., Guezoul, O., Bakria, M., Doumandji, S., Denys, C. (2015). Sélection des proies par la chouette effraie Tyto alba et le hibou moyen duc Asio otus dans un milieu agricole à El Mâalba (Djelfa, Algérie). Lebanese Science Journal, 16, 3-17.

Stoetzel, E., Fraysse, A., Grouard, S., Bochaton, C., Gala, M., Lenoble, A., Denys, C. (2016). Diet of the Lesser Antillean barn owl Tyto insularis (Aves: Strigiformes) in Dominica, Lesser Antilles. Caribbean Journal of Science, 49, 91-100.

Taberlet, P. (1983). Evaluation du rayon d'action moyen de la Chouette effraie, Tyto alba (Scopoli, 1769), a partir de ses pelotes de réjection. La Terre et la Vie, 38, 171-177.

Taylor, I. (1994). Barn Owls: predator-prey relationships and conservation. Cambridge, UK: Cambridge University Press.

Tores, M., Motro, Y., Motro, U., Yom-Tov, Y. (2005). The Barn Owl: a selective opportunist predator. Israel Journal of Zoology, 51, 349-360.

Venable, N.J. (1997). Birds of prey. Virginia: West Virginia University Extension Service.

Vivien, M.L. (1973). Régime et comportement alimentaire de quelques poissons des récifs coralliens de Tuléar (Madagascar). La Terre et la Vie, 27, 551-577. 